\title{
Outbreak of trichinellosis in eastern Slovakia
}

\author{
Z. PARALIČOVÁ ${ }^{1}$, J. KINČEKOVÁ ${ }^{2}$, I. SCHRÉTER ${ }^{1}$, P. JARČUŠKA ${ }^{1}$, P. DUBINSKÝ jr. ${ }^{3}$, \\ Š. PORUBČIN ${ }^{1}$, J. PAVLINOVÁ ${ }^{2}$, P. KRISTIAN ${ }^{1}$
}

${ }^{1}$ Department of Infectology and Travel Medicine, University Hospital, Rastislavova 43, Košice; ${ }^{2}$ Parasitological Institute SAS, Hlinkova 3, Košice; ${ }^{3}$ East Slovakia Institute of Oncology, Rastislavova 43, Košice

\begin{abstract}
Summary
Trichinellosis is a zoonosis caused by ingestion of undercooked raw meat from animals that harbour infectious larvae. In most of the Slovak regions there is ongoing life cycle of circulating trichinellosis in wild carnivores and wild boar population. The outbreak of trichinellosis occured in Rožňava district east Slovakia during spring in 2008. Ten members of farmer's family and their relatives got ill while processing meat from home-made pig-slaughter for meals and meat products intended for wedding dinner. During the meat processing all of them tasted raw meat. Moreover, another 45 persons were exposed to this infection by eating heat-treated meat products. The most common predominant clinical signs were: myalgias, fever, fatigue, exanthema and periorbital oedema. On the 40th day after infection there were intermediate to high titres of trichinella $\operatorname{IgG}$ antibodies detected (10 patients), high levels of eosinophilia (10 patients) with maximum of 6.76 x $10 \% / 1(55 \%)$ and profound changes in selected laboratory parameters: decreased levels of total proteins, increased levels of alpha 1-globulin and $\mathrm{C}$ reactive protein. Presence of IgG antibodies as well as aforementioned laboratory parameters was important markers of trichinellosis in our study, whereas other laboratory changes (leukocytosis, high levels of activity lactate dehydrogenase and creatine kinase) were detected only in few hospitalized patients.
\end{abstract}

\section{Introduction}

Trichinellosis is a parasitic disease affecting different vertebrate species caused by nematodes of the genus Trichinella, which are among the most common zoonotic pathogens worldwide. Out of 198 countries, only 92 have not yet reported Trichinella infection. Human trichinellosis has been reported from 55 countries, mainly within Europe and Asia (23 and 18 respectively). The overall annual incidence reaches 10000 cases with $0.2 \%$ mortality (Pozio, 2007).
Humans become occasional hosts after ingestion of undercooked meat infected with Trichinella larvae. Most of the acquired infections are asymptomatic, however, massive infection can lead to development of clinical signs that can rarely progress to a life threatening disease. Symptoms intensity in Trichinella infection depends on the amount of ingested viable larvae, Trichinella species and host factors. The first stage of the disease, caused by the presence of mature parasites in the intestine, is manifested by gastrointestinal symptoms. Following the second week post infection, newborn larvae migrate through intestine wall via blood strem is followed by systemic spread. The primary site of larvae location is in the skeletal muscles, manifested by painfull myositis. Common concomitant symptoms include fever, fatigue, periorbital oedema, headache and rarely exanthema. Among the more severe organ manifestations of Trichinella infection are myocarditis, meningitis and pneumonia that may sometimes be fatal.

In Slovakia, as well as in most of the neighbouring countries trichinellosis occurs mainly in wild animals. In Poland and Ukraine domestic pigs can also be infected. Meat from domestic pigs and wild boar population is the most common source of human infection (Nöckler et al., 2004; Svobodová et al., 2006).

There are three species out of eight and three genotypes circulating in wild animals in Slovakia, all belonging to Trichinella genus (Hurníková et al., 2007). The most common species is $T$. britovi while $T$. spiralis and $T$. pseudospiralis occur only sporadically. There were several small outbreaks of trichinellosis observed in eastern Slovakia in the past (Bilčíková et al., 1984; Mittermayer et al., 1987). T. britovi was also the causative agent in the largest outbreak in Slovakia in Brezno distrikt in 1998. Sausages containing dog meat were then idetified as the source of infection. There were 336 cases reported based on clinical symptoms and serological diagnosis (Dubinský et al., 1998; Ondriska et al., 2000). Smaller outbreak with 11 


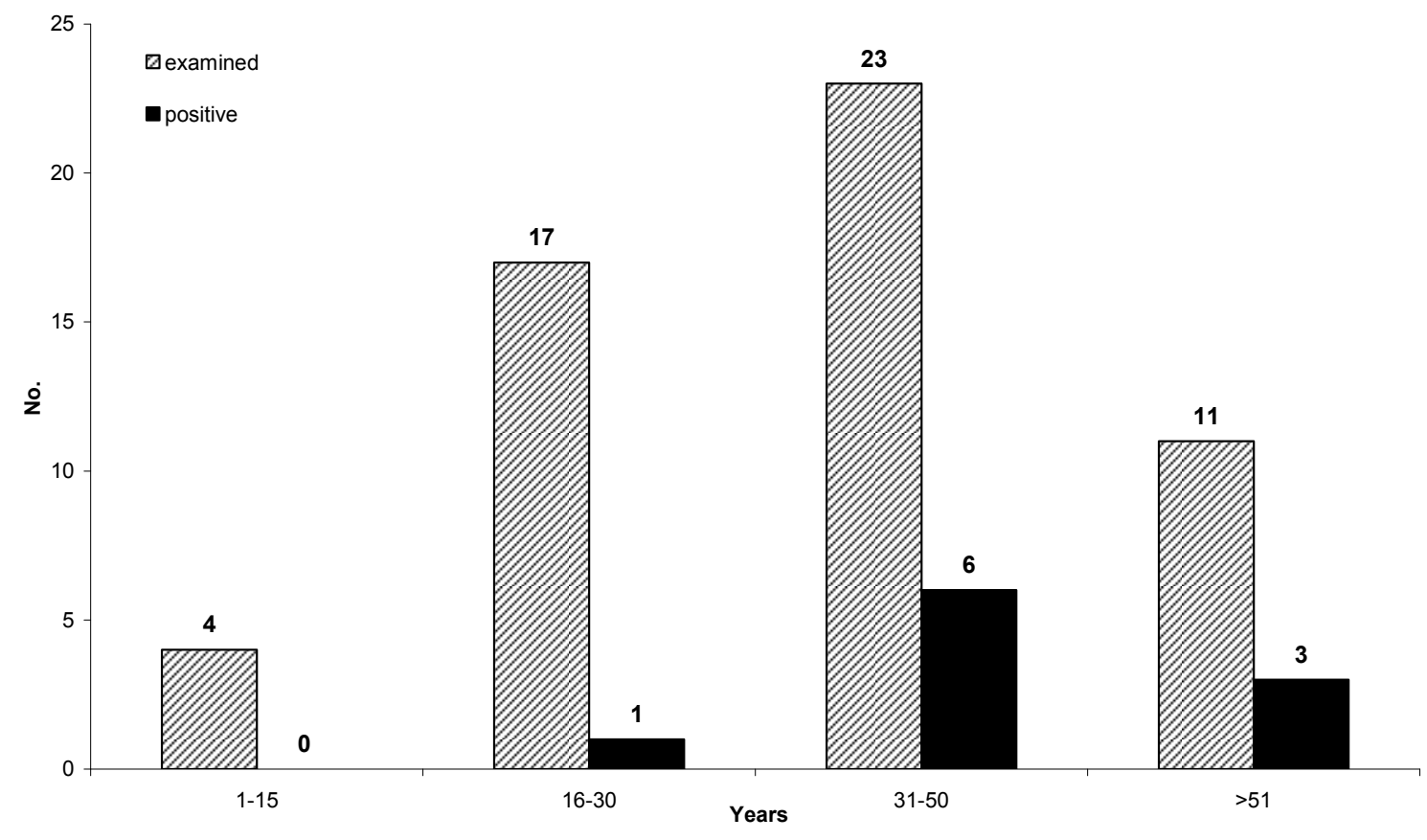

Fig. 1. Outbreak of trichinellosis in eastern Slovakia in the year 2008

confirmed cases of trichinellosis was reported from Komarno district in 2001. The source of infection was pork meat infected with T. spiralis (Reiterová et al., 2007). During the spring of 2008 there was another outbreak of trichinellosis after ingestion of pork meat from pig slaughtered at home and subsequently during wedding dinner in district Rožňava. The causative pathogen in pork meat and sausages was classified as T. britovi (Dubinský et al., 2008).

The aim of our work is to analyse epidemiological, clinical and laboratory findings in patients with suspected Trichinella infection and applied anthelmintic treatment.

\section{Patients and Methods}

\section{Patients}

From May to July 2008, there was a small outbreak of trichinellosis in eastern Slovakia. The late May, a farmer's family processed pork meat from home slaughtered pig without any veterinary inspection. Processed products were served during a wedding dinner. Due to the fact that several wedding guests manifested non-specific gastrointestinal symptoms, all 55 attendants were evaluated at the outpatient infectology department in Rožňava. Out of 55 persons, 16 patients were admitted to the hospital at the Department of Infectology and Travel Medicine, University Hospital Košice, with suspected trichinellosis, within $18-$ 30 days after ingestion of meat products. Their age varied from 22 to 80 years with the mean age 43.6 years. All hospitalized patients were treated with mebendazol or albendazol in therapeutic doses. More severe cases were treated in combination with prednisolone.
In all patients, epidemiological data, lenght of incubation period, clinical symptoms and laboratoty tests were evaluated. Laboratory tests were as follows: complete blood count, total protein (TP), albumin, globulin fractions (alpha 1, alpha 2, beta, gamma), C reactive protein (CRP), lactate dehydrogenase (LDH) and creatine kinase (CK). The levels of specific anti-Trichinella antibodies were repeatedly evaluated at the time of admission (day $18-30$ post ingestion), on day 40, and three, five and seven months p.i.

\section{Serological tests}

Anti-Trichinella specific IgG antibodies were examined in all 55 patients by indirect enzyme-linked immunosorbent assay (ELISA) with ES antigens (at a concentration of 1.5 $\mathrm{mg} / \mathrm{ml}$ ) of Trichinella spiralis and T. britovi, according to a method published Havasiová and Dubinský (1994). Cut off values were determined by the average absorbance values of negative control sera plus three standard deviations (SD). Positive sera of ten patients with trichinellosis were also tested by Western-blot. Electrophoresis was performed using a Bio-Rad Mini Slab Cell.

\section{Results}

Collected data from 55 examined persons were subject to an epidemiological analysis. Patients' age distribution and number of positive serological results are shown in Fig. 1. Ten out of 16 hospitalized patients, directly ingested of raw meat while processing meat. Another six persons consumed heat-treated meat products during the wedding dinner. Various clinical symptoms were present in 14 patients. These clinical symptoms have manifested between 
day 18 to 30 after ingestion of infected meat (the mean incubation period of 27 days). Gastrointestinal symptoms suggesting the first stage of trichinella infection were present only in 3 patients. Most common clinical symptoms were myalgias, fever, exanthema and fatigue. Specific antiTrichinella antibodies and other haematological and biochemical test sugesting trichinellosis were detected only in 10 patients (Table 1 and 2). Therefore only this cohort of 10 patients was considered as being infected with trichinellosis. Almost all of them tasted raw meat. When reviewing their medical history they complained of myalgias of various severity (9 patients), fever (10) and fatigue (6). Exathema was present in sixt patients and periorbital oedema in four patients.

Table 1. Signs and symptoms in patients

\begin{tabular}{lcc}
\hline Signs and symptoms & $\begin{array}{c}\text { Hospitalized } \\
\text { (N 16) }\end{array}$ & $\begin{array}{c}\text { Positive } \\
\text { (N 10) }\end{array}$ \\
\hline Myalgia & 13 & 9 \\
Fever & 15 & 10 \\
Fatigue & 11 & 6 \\
Exanthema & 6 & 6 \\
Periorbital oedema & 4 & 4 \\
Diarrhoea & 3 & 1 \\
Cephalea & 2 & 2 \\
Asymptomatic & 1 & 0 \\
Anti-Trichinella antibody & 10 & 10 \\
& & \\
\hline N-Number of patients & &
\end{tabular}

Five out of another six hospitalized patients have reported fever, three myalgias, and one fatigue. Two of those patients developed fever during hospitalization. None of them manifested positive anti-Trichinella antibodies, eosinophilia or increased levels of alpha 1-globulin and only two patients had increased levels of $\mathrm{C}$ reactive protein. showed elevation of LDH activity with mean value of 4.81 $\pm 0.91 \mu \mathrm{kat} / 1$ and four patients had elevated activity of $\mathrm{CK}$ with mean value of $5.44 \pm 2.19 \mathrm{ukat} / \mathrm{l}$.

High levels of anti-Tichinella antibodies were present only in two patients immediately after their admission, i.e. from day 18 to 30 after aquiring infection. Intermediate levels of antibodies were present in one patient and another four patients showed borderline titre levels (Table 3). Marked seroconversion resulted in the fact that 40 days post infection intermediate titres were present only in single patient, all other patients had high levels of antibody titres. In three patients high levels of antibody titres remained elevated for seven months p. i., while in all others antibody titres dropped to low levels or disappeared completely.

In almost all patients with trichinellosis, confirmed by the positive specific anti-Trichinella IgG antibodies, four laboratory parameters were altered: eosinophilia, decreased levels of total protein, increased levels of alpha 1-globulin and CRP.

\section{Discusion}

Dupouy-Camet et al., (2002) stated that the clinical diagnosis of trichinellosis is difficult as there are no specific pathognomic signs and symptoms. They have elaborated an algorithm that includes 4 groups of symptoms typical for an acute trichinellosis. The diagnosis of trichinellosis is confirmed if there is either one of the implied clinical symptoms, eosinophilia and elevated levels of muscle enzymes, as well as positive serology, seroconversion or detected larvae in muscle tissue.

Thus symptoms found in six patients who did not have eosinophilia and positive serology cannot be regarded as a proof of Trichinella infection. According to medical history of some patients, myalgias, fatigue and diarrhoea could be triggered psychologically as a reaction to the fact

Table 2. Hematological and biochemical parameters in pacients $(\mathrm{N}=10)$ with trichinellosis

\begin{tabular}{lccc}
\hline \multicolumn{1}{c}{ Parameters } & Unit & $\begin{array}{c}\text { Values suppressed**, } \\
\text { increased }\end{array}$ & $\begin{array}{c}\text { Mean values } \pm \text { S.D. } \\
\text { suppressed*, } \\
\text { increased }\end{array}$ \\
\hline Eosinophils & $(0.0-0.25 .109 / 1)$ & 10 & $3.01 \pm 2.27$ \\
Total protein & $(66.0-87.0 \mathrm{~g} / \mathrm{l})$ & $9^{*}$ & $56.27 \pm 5.70 *$ \\
Alpha 1-globulín & $(1.6-3.7 \mathrm{~g} / \mathrm{l})$ & 9 & $5.23 \pm 1.16$ \\
C reactive protein & $(0-5 \mathrm{mg} / \mathrm{l})$ & 9 & $26.64 \pm 16.23$ \\
Lactate dehydrogenase & $(2.25-3.75 \mu \mathrm{kat} / \mathrm{l})$ & 5 & $4.81 \pm 0.91$ \\
(LDH) & $(0.2-2.9 \mu \mathrm{kat} / \mathrm{l})$ & 4 & $5.44 \pm 2.19$ \\
Creatine kinase $(\mathrm{CK})$ & & &
\end{tabular}

All patients with trichinellosis showed eosinophilia with mean value of $3.01 \pm 2.27 \times 10^{9} / 1$, and maximum value reached $6.76 \times 10^{9} / 1$. In relative reference, values ranged from $7 \%$ to $55 \%$ with mean value of $28.1 \pm 15 \%$. Levels of total protein were decreased in nine patients with mean value of $56.27 \pm 5.70 \mathrm{~g} / \mathrm{l}$ and levels of alpha 1-globulin and $\mathrm{C}$ reactive protein were increased with mean value of 5.23 $\pm 1.16 \%$ and $26.64 \pm 16.23 \mathrm{mg} / \mathrm{l}$ respectively. Five patients that their family members acquired Trichinella infection. Fever that was detected during hospitalization (four weeks p.i.) in tvo out of six patients might have had different etiology.

All ten patients with trichinellosis, despite having aforementioned clinical symptoms, showed positive serology and eosinophilia. Nine of them had decreased levels of total protein. Campbell (1983) considers this parameter in 
Table 3. Dynamics of IgG anti-Trichinella antibodies in infected patients

\begin{tabular}{cccccc}
\hline Pacient No. & 18th - 30th day & 40th day & 3rd month & 5th month & 7th month \\
\hline 1 & 0 & 1078 & ND & 100 & 200 \\
2 & 100 & 1100 & 400 & 300 & ND \\
3 & 0 & 700 & 200 & 100 & 0 \\
4 & 3000 & 3000 & 3000 & 2400 & 3000 \\
5 & 3000 & 3000 & 2200 & 500 & 300 \\
6 & 100 & 3200 & ND & 100 & 0 \\
7 & 600 & 1900 & 200 & 100 & 0 \\
8 & 100 & 3000 & 600 & 200 & 100 \\
9 & 100 & 3000 & 3000 & 1500 & 3000 \\
10 & 0 & 2000 & 1000 & 400 & 2000 \\
\hline ND non detected & Low titer: $1: 200$ & Intermediate titer: $1: 400-800$ & High titer: $\geq 1: 1600$
\end{tabular}

trichinellosis to very common. Decreased levels of albumin are also thought to be a common finding, but we have observed this laboratory change only in five patients. Only some patients had increased levels of muscle enzymes LDH (5 patients) and CK (4 patients). However, we observed increased levels of $\mathrm{C}$ reactive protein and alpha 1globulins, which suggests that there is intensive muscle destruction during larval invasion (Dupouy-Camet et al., 2002). Production of CRP and alpha 1-globulin is caused by stimulating hepatocytes with IL-1, IL-6 and TNF-alpha cytokines. There was a marked increase in the levels of both reactants in 9 out of 10 patients. The intensity of clinical symptoms and laboratory changes depends on the Trichinella species, as well. Mentioned Tri-chinella outbreak was caused by $T$. britovi species (Dubin-ský et al., 2008). For humans and some animals this Tri-chinella species is less pathogenic than T. spiralis (Pozio et al., 2009). This phenomenon is explained by lower new-born larvae production of the females in gastrointestinal tract of the host (Dupouy-Camet et al., 2002). Immediate treatment of all hospitalized patients with antiparasitic agents was of major importance in stopping progression of clinical Trichinella infection. Antiparasitic agents kill all intestinelocated mature parasites and avoid entry of newly produced larvae into the circulation. Simultaneously, muscle larvae are killed, which in mild disease reduces the intensity of clinical symptoms and laboratory parameters (Kociecka et al., 1989; Watt et al., 2000). On the other hand killing larvae in heavily infected individuals made clinical symptoms worse in six patients. Antigens released from killed larvae prompted seroconversion, which resulted in the rise of antibody titres in all patients after the treatment on day 40 p.i.

Another important factor modify Trichinella infection course is the overall number of ingested larvae. According to analysis of Trichinella outbreaks, where number of ingested larvae from consumed meat was measured, the infective dose necessary to cause human disease is reported to be 70 to 150 muscle larvae of $T$. spiralis (Gould, 1970). However, not all larvae in ingested meat dish are infectious to humans. Many different factors (salt) can decrease infectiveness (Anonymus, 2005). Meat that was used for meat food was processed right immediately after the slaughtering of the pig. There was too little time for added salt and preservatives to be sufficiently effective in to reducing the larvae infectivity.

Taking the technological procedure when making home made meat products includes tasting the small amounts of raw meat from several portions of the mixture. Having experimentally simulated the procedure of sausage production, and we have found that during four tastings the patients could ingested approximately a $10 \mathrm{~g}$ of meat portion (divided $2.5 \mathrm{~g} \mathrm{x} 4$ ). Dubinský et al. (2008) found that in the products from the pork meat there was $14.5 \pm$ 11.3 larvae/g (LPG). Thus patients ingested approximately 145 T. britovi larvae (ranging from 32 to 258 larvae, and this dose was sufficient to cause trichinellosis (Takumi et al., 2009).

High antibody titres were accompanied also by marked variations in laboratory parameters in all hospitalized patients. In three patients (No 4, 9, 10 Tab. 3.), high levels of antibody titres remained elevated even after 7 months, while in others antibody titres dropped to low levels or disappeared. The antibody dynamics also points to the amount of infectious dose of Trichinella larvae. Kociecka (2000) reported similar prolonged IgG antibody elevation in human trichinellosis. Our seronegative patient also consumed meat products during wedding dinner, however those were heat-treated, which makes as assume that Trichinella larvae were already killed.

\section{Acknowledgement}

This study was supported by the Science Grant Agency 
VEGA (Grant No. 2/0134/09 and 2/7186/27). Special acknowledgement are due to MUDr. Irena Kopperová from the outpatient infectology department in Rožňava, for cooperation during follow-up and data analysis, and also to RNDr. František Ondriska, PhD., HPL inc., Bratislava for performing parallel antibody detection.

\section{References}

ANONYMUS (2005): Risk assesment of revised inspection slaughter animals in areas with low prevalence of Trichinella. EFSA Journal, 200: 1 - 41

BilčíKOVÁ, M., BILČíK, P., BoOR, A., LONGAUER, F., LAKATA, E., PORACKÁ, L., SCHRÉTER, I. (1984): Morfological and ultrastructural findings in the mucous membrane of small intestine at human trichinellosis after the mebendazole therapy. In Proceedings of National conference on zoonoses, October $24-26,1984$, Košice: $128-133$

CAMPBELl, W.C. (1983): Trichinella and Trichinosis. Plenum Pres, New York

Dubinský, P., HuRníkovÁ, Z., KinČEKOVÁ, J., ReITeROVÁ, K., ANTOlOVÁ, D., KERPAN, L., JuRIŠ, P., PliEŠOVSKÝ, J. (2008): Decade from the greatest outbreak of trichinellosis in Slovakia. Slov. Vet. J., 33 (4): $214-215$ (In Slovak)

DUBINSKÝ, P., TOMAŠOVIČOVÁ, O., REITEROVÁ, K., KinČEKOVÁ, J., RAKICKÝ, P., SOlÁR, I., ŠPAKUlOVÁ, M. (1998): Epidemiology of trichinellosis in Valaska. Slov. Vet. J., 23, 4: $181-185$

DupouY-CAMET, J., Kociecka, W., BRuschi, F., BolasFERnANDES, F., PozIO, E. (2002): Opinion on the diagnosis and treatment of human trichinelosis. Expert Opin. Pharmacother., 3: $1117-1130$

Gould, S. E. (1970): Clinical manifestations. B. Diagnosis. Gould, S. E. (Ed.) Trichinosis in man and animals. C. C. Thomas Publisher, Springfield: $307-328$

HAVASSIOVA, K., DuBINSKÝ, P. (1994): Antibody response during the course of human trichinellosis. CAMPBELL, W. C., Pozio, E., BRUschi, F. (Eds.). Trichinellosis. ISS Press, Rome: $505-510$

Hurníková, Z., Chovancová, B., BartKová, D., DUBINSKÝ, P. (2007): The role of wild carnivores in the maintenance of trichinellosis in the Tatras National Park, Slovakia. Helminthologia, 44: 18 - 20
KocIEcKA, W. (2000): Trichinellosis: human disease, diagnosis and treatment. Vet. Parasitol., 93: 365 - 383

Kociecka, W., StefaniaK, J., KacPrazaK, E., PAKUla, M. (1989): Clinical evaluation of albendazole in the therapy of human trichinellosis. Wiad. Parasitol., 34: 457 $-466$

MitTermayer, T., MARCineK, G., Bejdova, D., UHLÍKOVÁ, M., HÜBNER, J.(1987): Incidence of trichinellosis in Bardejov district in 1985. The ELISA reaction in the diagnosis of human trichinellosis. Čas. Lek. Českých., 10: $878-881$

NöcKler, K., Hamidi, A., Fries, R., Heidrich, J., BecK, R., MARINCULIČ, A. (2004): Influence of methods for Trichinella detection in pigs from endemic and nonendemic European region. J. Vet. Med. B Infect. Dis. Vet. Public Health, 51: 297 - 301

Ondriska, F., Pochybová, M., Kultan, V., SMieŠna, A., LESŇÁKOVÁ, M., DAŇOVÁ, K., MihalkovÁ, V., DulíkovÁ, M., KuchtovÁ, M., LíšKA, M., STRHÁROVÁ, A. (2000): Regional incidence of human trichinellosis outside the outbreak focus. Helminthologia, 37: $67-70$ POZIO, E. (2007): World distribution of Trichinella spp. infections in animals and humans. Vet. Parasitol., 149: 3 21

Pozio, E., Rinaldi, L., Marucci, G., Musella, V., Galati, F., Gribgoli, G., Boireau, P., LA Rosa, G. (2009): Hosts and habitats of Trichinella spiralis and Trichinella britovi in Europe. Int. J. Parasitol., 39: 71 - 79 Reiterova, K., KinceKova, J., Šnabel, V., MARUCCI. G., POZIO, E., DUBINSKÝ, P. (2007): Trichinella spiralis outbreak in the Slovak Republic. Infection, 35: 89 - 93

Svobodová, V., Dubinský, P., CABAJ, W., Sréter, T. (2006): Risk of diseases obtained in nature and foodborne. Noviko, Brno. (In Slovak)

Takumi, K., Tenuis, P., Fonville, M., Valle, I., Boireau, P., Nockler, K., Giessen Van Der, J. (2009): Transmission risk of human trichinellosis. Vet. Parasitol., 159: $324-32$..

Watt, G., SAisorn, S., Jongsakul, K., SAKolvaree, Y., Chaicumpa, W. (2000): Blinded placebo-controlled trial of antiparasitic drugs for trichinosis myositis. J. Infec. Dis., 182: $371-374$ 